\title{
On fashion and fashion discourses ${ }^{1}$
}

\author{
Keywords \\ fashion \\ critical views \\ social conversation \\ civilizing process \\ individualization \\ self-expression \\ identity \\ 1. This text is the product \\ of a re-elaboration of \\ different materials \\ previously published in \\ Spanish and Italian.
}

\begin{abstract}
While critical views inherited from the past still influence our appraisal of fashion, its pervasiveness in contemporary society calls for an explanation. In this article I attempt to show how the importance of fashion in our society is the result of a combination of a structurally modern space and Romantic cultural ideals. I conclude that, despite its frivolous appearance, fashion is not only a powerful social indicator, but also a particular means of bringing together the diverse and often contradictory demands of our human nature through a peculiar exercise of practical judgment.
\end{abstract}

The prominence of fashion in our societies demands an explanation and, although this kind of explanation is usually reserved for sociologists, it is also true that changes in society have become one of the dominant issues in philosophical discourse. A glance at contemporary philosophy shows that social issues have become the starting point - and sometimes even the finishing line - for a large section of philosophical debate or, at least, of philosophical debate which is 'relevant' (from a sociological point of view). Whatever the case, this justifies philosophy's novel interest in fashion, an interest that in no way replaces that of the sociologist since the philosopher approaches social life, 
including fashion, as one of its most striking symbols, with his usual questions - those referring, in the end, to being and changing, to identity and flux, reality and appearance.

From this perspective, the fact that fashion should attract the attention of a philosopher is quite logical. Fashion brings us an ever-changing spectacle (especially accelerated in recent times). It is not simply a social fact or a 'total social fact', as stated by Mauss (1968: 274). It is not merely a coercive fact that imposes its law on the most reluctant individuals; rather, in its apparent superficiality, it implies a deeper dynamic, rooted at the very heart of human life (from which it is extremely difficult to escape precisely because we are social beings). It implies a dynamic of social assimilation and distinction, which, for want of other references, could be postulated as a guiding criterion that determines our very identity.

However, could this really happen? What would social life have to be like? What ideas and values would have to fill (or leave) our minds to allow fashion to set itself up as a criterion for identity? There is every likelihood that fashion cannot take on this responsibility without belying itself - its core is change - and without belying identity, watering it down in fleeting processes, which, in practice, would mean the annulling of all and every project for identity. The fact that, in postmodern times, fashion has been able to present itself as a factor of idenity is a clear sign that, contrary to the common philosophical idea, neither fashion, nor thinking on fashion, imply frivolity.

In fact, it may be true that fashion, despite the contempt in which it has long been held in intellectual milieus, is not so frivolous after all; if we consider that it very clearly reflects our social condition and shows the personal expression of a plurality of human dimensions. Indeed, the way we use fashion - therefore both the way we follow or do not follow it - is evidence of how we situate ourselves in the social world that we inhabit. Without a doubt, it is a powerful social indicator of the position we occupy in the fashion system: as originators or followers of tendencies, as punctual or late followers, as creators or consumers, etc. All this in itself very clearly marks the relative importance we give to a certain kind of common sense and social mobility, but, above all, the use we make of fashion is a way of expressing, in a visible material way, our particular means of bringing together the diverse demands of our human nature, and of doing so with the resources at our disposition, in a specific situation. Thus, the use of fashion means exercising practical judgement; in short, it is an exercise in discretion.

Therefore, the contemporary exaltation of fashion seems - in some postmodern circles at least - to reflect an explicit cult of the most brilliant and seductive aspects of consumer society. But, behind this affected and sometimes perverse exaltation of what is considered, correctly or not, to belong to the area of pure amusement, fashion continues as a social phenomenon that needs a balanced explanation. This will help place it in the general context of human life, in the general context of a life that, as seen by Simmel, takes place at the intersection of a variety of social spheres, and that, for this very reason, cannot be reduced to what prevails in just one of them. 
Specifically, while the pervasiveness of fashion in our society calls for a structural explanation, this sort of approach should not obscure the individualized nature of fashion behaviours.

That structural explanation should certainly take into account the social differentiation following the modernization and industrialization process, as well as the acceleration of social time derived thereof; it must also consider the Romantic inheritance that is at the root of the contemporary focus on self-expression and identity.

Nevertheless, it is important to note that while the industrial revolution has certainly influenced the ways in which some fashions are generated and disseminated, romanticism has also increased our consideration of self-expression. Neither of those changes has modified the elusive nature of fashion itself or its ambivalent dynamics of social assimilation and distinction - a dynamic that emerges in unpredictable ways, provided some sort of society exists.

In the following pages I have taken both kinds of reflections into account, in order to understand how the two approaches are linked: the ubiquitous dynamic of fashion in our society and its often discrete presence in our daily lives, where the use of fashion is, in the end, an exercise in judgement or discretion

With this in mind, I begin by giving a quick summary of two critical views of fashion inherited from the past that still influence the present; I then continue to address fashion as a phenomenon which shapes the social area - an area which modern philosophers, somewhat ambivalently, considered as linked to the civilization process. Fashion is a phenomenon, which, at any rate, can only increase in influence, and may change completely in a world where words are being replaced by images, and where the Romantic ideal becomes more prominent due to the modern insistence that these conventions equate with social order. In line with this thinking, we could say that, although there is a certain structural affinity between fashion and modernity, the importance of fashion in our society is the result of a combination of a structurally modern social space and Romantic cultural ideals.

\section{Metaphysicians and politicians: Two critical visions of fashion}

The frequent lack of interest in fashion among intellectuals has some eminent precedents. Plato and Rousseau perfectly embody the main two criticisms of fashion: the former metaphysical and the latter political.

In his well-known allegory of the cave, Plato portrayed prisoners as being chained to shadows, and only the free man dared leave the cave and see things are they truly are. On the contrary, those who remain in the cave, enslaved and fascinated by the shadow of things, will never know reality. This text suggests that, as they are enslaved in spirit by the shadows, the prisoners would go so far as to kill anyone who should dare to suggest that true reality lies elsewhere. Nevertheless, in Plato's proposition, there is no doubt that fashion belongs to the shadows. In Hippias Major 
for example, Plato dwells on the relationship between clothing and beauty using the terminology of fraud [Plato 1982: $294 \mathrm{a}-\mathrm{b}$ ]. It is clear that fashion, which undergoes constant change, is the antithesis of Plato's immutable ideas, which are the only thing truly real. When describing those involved in the world of fashion, we could use Plato's description of the Sophists, who he referred to as 'experts in producing appearances'. (Plato 1995, Sophist, 236 c)

If Plato can be taken as the main philosopher to scorn fashion for metaphysical reasons, Rousseau may be considered the reference point for those intellectuals who look down on fashion for political reasons. And if Plato's criticism has the virtue of attracting those of a religious nature, the path taken by Rousseau bears a certain similarity to Marxist criticism of fashion. (The case of Thomas More, who, in Utopia, describes a fashionless society, belongs, to my mind, to the former group, although, as it is a political treatise, it has been frequently associated with the latter.)

In fact, Rousseau elaborated his political theory in open disagreement with the society of his day, which, unmistakably, had given up the gravity and nobility of classical republican virtue and had surrendered to the enjoyment of private life. Instead of concerning themselves with public life, the nobility - in a process, which, according to Elizabeth Wilson, began towards the end of the Middle Ages (Barnard 1996: 147-8), and according to Fernand Braudel in the sixteenth century (Finkelstein 1998: 6) - were devoted to courtly life, while the bourgeoisie was devoted to business. Looking around him, Rousseau only saw the collapse of republican ideals: the transformation of the republican citizen who had been committed to the good of the republic into either a narcissistic aristocrat or a bourgeois caught up in his own private interests and with copying the whims of the aristocracy. Thus, Jean Jacques concludes that society corrupts; at any rate, it corrupts republican virtue, formulated as a virtue in which one places the common good before private interest. A similar idea is found in Smith when he writes:

In quiet and peaceable times, when the storm is at a distance, the prince, or great man, wishes only to be amused, and is even apt to fancy that he has scarce any occasion for the service of any body, or that those who amuse him are sufficiently able to serve him. The external graces, the frivolous accomplishments of that impertinent and foolish thing called a man of fashion, are commonly more admired than the solid and masculine virtues of a warrior, a statesman, a philosopher, or a legislator. All the great and awful virtues, all the virtues which can fit, either for the council, the senate, or the field, are, by the insolent and insignificant flatterers, who commonly figure the most in such corrupted societies, held in the utmost contempt and derision.

(Smith 1982: 63)

Rousseau and Smith both refer to social spaces that are governed by the games of seeing and being seen, where human beings vie with one another in an originally corrupt process which must, of 
2. Even from a theological perspective, such a vision of social life seems to reflect a unilateral reading of 'the world' or 'human realities' used in the Saint John sense as 'lust of the flesh, of the "lust or the flesh, of the eye, and of power-in short, the world as synonym of 'what is mundane' and ignoring another radically positive meaning of 'the world' which also enjoys theological prestige: the world as an originally good reality and thus, not necessarily subject to a corrupt logic. necessity, give rise to envy and rivalry. However, this sequence of 'society-vanity-rivalry', which is also very evident in all later social thinking, disturbingly implies that all social dynamics - including fashion - are basically corrupt. ${ }^{2}$

Conversely, the importance of the fashion phenomenon in modern societies suggests that it should be studied in a different light, allowing for a positive approach to the subject. This is even more crucial, as we will soon see, in that the contemporary effervescence of fashion brings essential issues into play which refer to the definition of one's own identity (González 2007). We must not forget that Plato gave no clear answer to this question. By placing reality beyond appearances, he leaves us defenceless in a world dominated by appearances. In this situation, his only option is to escape from such a world, perhaps to travel to 'Utopia'. But that would mean abandoning society to that corrupt logic glimpsed by Rousseau, and echoed by Kant in his description of the 'predisposition to humanity':

The predispositions to humanity can be brought under the general title of a self-love which is physical and yet involves comparison (for which reason is required); that is, only in comparison with others does one judge oneself happy or unhappy. Out of this self-love originates the inclination to gain worth in the opinion of others, originally, of course, merely equal worth: not allowing anyone superiority over oneself, bound up with the constant anxiety that others might be striving for ascendancy; but from this arises gradually an unjust desire to acquire superiority for oneself over others. Upon this, namely, upon jealously and rivalry, can be grafted the greatest vices of secret or open hostility to all whom we consider alien to us. These vices, however, do not really issue from nature as their root but are rather inclinations, in the face of the anxious endeavour of others to attain a hateful superiority over us, to procure it for ourselves over them for the sake of security, as preventive measure; for nature itself wanted to use the idea of such a competitiveness (which in itself does not exclude reciprocal love) as only an incentive to culture.

(Kant [1793] 1998, Religion, 6: 27)

By differentiating - in the same work - between 'predispositions to humanity' and 'predispositions to personality', Kant emphasizes that this cultural incentive is not necessarily an incentive towards morality (González 2004). Despite this, we can ask if this logic of comparison and rivalry, which, in Kant's own words, is a constituent of culture, really does represent the only social logic, and how the hostility that derives from this logic can be neutralized? It is important to formulate these questions and even more so to answer them - because, clearly, we live in a world that is fuller of appearance than that of Rousseau or of Kant and this leads to a never-ending comparison; in front of our eyes there is a daily parade of innumerable, often contradictory, models, which have no personality and 
are simply pure image. This is perhaps one of the points that differentiates our society from those of earlier ones: the rule of image.

\section{The shaping of the social space through words or images}

In order to define man as social and political animal, Aristotle drew on a feature that distinguishes man from the other animals, and which allows the former to be considered the 'most social' of all animals: the word. Only man has not simply a voice - with which he shows states of pleasure and pain - but also words, with which to speak 'of what is just and unjust, useful and hurtful'. ${ }^{3}$ For Aristotle, then, human sociability stands out due to its verbal capacity, which is at the service of the ethical nature of man. In contrast, Rousseau's criticism of the society of his day suggests a very different concept of society, where the centre has shifted from the word to sight, from the ears to the eyes.

Word and action, in Hannah Arendt's view, were the keys to the classical political world. However, as Richard Sennet has observed, sight and appearance triumph in the modern world (Sennet 1997). Thus, however, imitation, which is such a central characteristic of human sociability and, according to Aristotle in his Poetics, plays a key role in the process of learning, has many and diverse contents. Imitation of the exploits sung by poets is clearly different from imitation of the more or less brilliant appearance of impersonal, distant models who parade before our eyes as if they were on a stage. Nevertheless, it is in this latter space - the space for 'what is social' - that fashion apparently develops, with the backing - as Smith reminds us - of our willingness to admire and imitate the great.

It is from our disposition to admire, and consequently to imitate, the rich and the great, that they are enabled to set, or to lead what is called the fashion. Their dress is the fashionable dress; the language of their conversation, the fashionable style; their air and deportment, the fashionable behaviour. Even their vices and follies are fashionable; and the greater part of men are proud to imitate and resemble them in the very qualities which dishonour and degrade them ...

(Smith 1982: 64)

Kant uses similar terminology in Anthropology:

It is a natural inclination of man - says Kant - to compare his behaviour to that of a more important person (the child compares itself to grown-ups, and the lowly compares himself to the aristocrat) in order to imitate the other person's ways. A law of such imitation, which aims at not appearing less important than others, especially when no regard is paid to gaining any profit from it, is called fashion. Therefore it belongs under the title of vanity, because in its intention there is no inner value; at the same time, it belongs under the title of folly, because
3. "That is not the fashion which everybody

wears, but which those wear who are of a high rank, or character. The graceful, the easy, and commanding manners of the oreat joined to of the great, joined to the usual richness and magnificence of their dress, give a grace to the very form which they happen to bestow upon it. As long as they continue to use this form, it is connected in our imaginations with the idea of something that is genteel and is genteel and magnificent, and should be indifferent, it should be indifferent, it
seems, on account of seems, on account of
this relation, to have something about it that is genteel and magnificent too. As soon as they drop it, it loses all the grace, which it had appeared to possess before and being now used only by the in used only by the inferior ranks of people seems to have something of their meanness and awkwardness' (Smith 1982: 194-195). 
4. 'It is necessary for us, in our calm judgment and discourse concerning the characters of men, to neglect all these differences, and rende differences, and render public and social. The intercourse of intercourse of sentiments, therefore, in society and conversation, makes us form some general unalterable standard, by which we may approve or disapprove of characters and manners' (Hume [1777] 1975: 228-230). in fashion there is still a compulsion to subject oneself slavishly to the mere example which many in society project to us.

(Kant [1793] 1998, 7: 245)

The scornful tone used by both Smith and Kant when referring to fashion is due to the fact that they believe fashion to be mere vanity, and, simultaneously, they warn that, under the influence of fashion, human beings may behave in ways that are contrary to common sense and morality. But this is precisely proof of the strength of human sociability, encouraged, as both authors mention, by the desire to imitate the great (Aristotle [1991]: 1253a 12). Although a study of contemporary fashion may belie this last point - much fashion has its roots at the street level or in a subculture - the opposite argument is also valid: what has changed is not so much the origin of fashion as the evaluation of who is great or not.

Whatever the case, we must not forget that Kant himself considers this social logic, arbitrated by imitation, as a factor in civilization and refinement - although not of a moral nature - as, in line with Rousseau, he believes that refinement is compatible with the hypocrisy that corrupts the heart (Kant, [1911] 1998, KrV A748/B777). In contrast, Hume has a more positive vision of civilization and its relationship with morality. It is precisely in the moral work of Hume - specifically his theory on the artificial virtues - that we find presentation of the elements of a modern theory of civilization. Here we find the artificial institution of a framework for justice in which commercial activity and the progress of moral sentiments are developed (Baier 1991). This goes hand-in-hand with the 'social conversation' that generates 'common sense'.

Indeed, in a notorious anticipation of the social theory of contemporary social theorists such as Elias (Elias 1997) or Bourdieu (Bourdieu 2002), Hume observes with great clarity that the widening of the circle of conversation required by the transition from family to civil society, involves important modifications of our feelings. He summarizes the nature of these modifications when he speaks of 'making more public our sentiments'. ${ }^{4}$ This process takes place when we model those sentiments according to more general criteria that are formed with relative spontaneity; when we feel the need to make ourselves understandable to others in conversation. This social reality - in which Rousseau sees mostly deception - is what, according to Hume, leads to the refinement of our feelings, because it involves a deprivation of the element of passion with which those feelings appear in the first place, and, to a certain extent, make them objective and open to institutional regulation.

The institutional regulation of sentiments has much to do with the importance that Hume concedes to the rules of courtesy, which make up the 'art of pleasing', and, among those rules particularly, the conventional rules referring to social commerce among men and women (Hume [1882] 1964: 192). The logic of this social commerce is, ideally, what is reflected in the literary salons so well described by Simmel: a relatively egalitarian logic, based precisely on emphasizing the purely formal elements of sociability. 
Indeed, the literary salon created an atmosphere that made treating one another as equals possible. This is also what Dena Goodman has in mind as she notes that in the salon one set of differences, based on birth, was devalued and replaced with another, based on comportment, manners, and a shared discourse. To be civil was to act nobly, and thus to be noble. Nobles were people who shared a set of manners and a discourse, both of which were defined by rules of comportment regulating how they were to relate to one another as persons who were admittedly different in a society defined by ranks and orders (Goodman 2001: 132). That sort of society was what the Enlightenment thinkers had in mind as a model for civil society itself. ${ }^{5}$

The echo of Scottish thinking on society is also found in the Kantian characterization of the world as a Shauplatz (Kant [1802] 1923, 9:18), as a Weltbühne (Kant [1784] 1983, 8: 17), or a social stage. However, it is precisely in the way modern society tends to pave the way for the world as a stage that it prepares the ground for the postmodern hegemony of fashion.

Certainly the main difference between modern and postmodern society on the subject of fashion is not so much structural as cultural: whereas modern society gave greater importance to the word albeit a formal word in consonance with the demands of 'social conversation' - postmodernity grants greater importance to one's image. The hegemony of the word has been replaced by the hegemony of sight. Thus fashion has been strengthened exponentially, perhaps to regulate that which in a social context of 'institutionalized individualism' (Beck 2002) runs the risk of becoming a 'visual cacophony' (Finkelstein 1998: 18). Indeed: as Anne Hollander observes, 'The tyranny of fashion itself has in fact never been stronger than in this period of visual pluralism' (Finkelstein 1998: 18). In any case, the regulation of this pluralism occurs within the context of a social space that, structurally, is still modern, in that what we call postmodernity may be, from a certain view, considered an ambiguous continuation of modernity.

From a cultural perspective also, there is no doubt that modern heritage is relevant in understanding the contemporary destiny of fashion. As we have stated, Rousseau's thesis, which links civilization and corruption, is at the foundation of most modern thinking on society. In this line, vanity and the social vices in general were believed by modern thinkers to be factors for progress and civilization. Mandeville states that the economy advances due to vanity, which promotes rivalry in expenditure; Kant believes that social vices, although blameworthy at an individual level, temper the coarseness of natural leanings, and so, from a historical perspective, may be considered civilizing factors. Thus, despite not having dealt specifically with the phenomenon of fashion, these modern authors proposed a thesis which still frames the postmodern reflections on fashion: for example Lipovetsky, who writes: 'The more ephemeral seduction there is, the more enlightenment advances' (Lipovetsky 1994: 9). Hegel's thesis on the 'Cunning of reason' is itself a secularization of the Christian idea of Providence: what may be fatal individually, may aid the progress of reason at a macro-historical level
5. 'Commerce, conversation,

Enlightenment itself, were all created out of a culture of interaction and exchange among groups and individuals whose differences mose cifferes made such relations meaningful rather than tautological, but which also necessitated rules, structures, and institutions to make them work. The philosophers soon looked to salon conversation not only to structure the work of Enlightenment, but as the model for civil society itself'

(Goodman 2001: 134). 
Certainly, Lipovetsky gives an aestheticist twist to Hegel's thesis. On the one hand, he believes that fashion obeys what is fanciful, ludic, and apparently irrational. But at the same time he holds that fashion has played its role in the modern project for the progressive liberation of the individual:

The age of efficiency and the age of the ephemeral, rational mastery of nature and the ludic follies of fashion: these are only in appearance antinomic. In fact, the two types of logic are rigorously parallel ... In each case, human sovereignty and autonomy are affirmed, exercising their dominion over the natural world as they do over their aesthetic décor.

(Lipovetsky 1994: 24)

However, in spite of these structural and cultural continuities with modernity, the contemporary effervescence of fashion, at a cultural level, owes a great deal more to Romantic expressivity, which is culturally possible - as Simmel observed - due to the differentiation of the individual promoted by the process of modernization.

Indeed, Simmel differentiates between two kinds of individualism: on the one hand, the individualism of the eighteenth century, which we can associate with emancipation, which was promoted by the Enlightenment and claimed that all human beings have equal rights. On the other, we have the individualism of the nineteenth century, which is the characteristic achievement of Romanticism: every single human being is unique in kind, and true freedom also involves the expression of that uniqueness. Simmel calls the former type of individualism 'numerical individualism (Simmel 1971: 224), and he believes it to be structurally possible due to the intersection of social circles in which the modern individual ordinarily lives. The second type of individualism, conversely, is called 'qualitative individualism', and it first became possible when the intersection of social spheres left a free space within which the individual, no longer subject to extrinsic norms, could find a space for an original expression of the self. 'Authenticity', instead of courtesy, is then able to thrive as the dominating value in human interaction (Taylor 1992). The self has to appear such as it is without cultural mediation.

\section{The affinity between fashion and modernity}

'Fashion' represents a peculiar expression of what Kant once described as 'antisocial human sociability' (Kant [1784] 1983, Idea 8: 20-21), that is, the inclination that at times makes us want to associate with our fellow beings and at others to sever connections with them. As is common knowledge, Simmel explains the fashion phenomenon on the basis of that principle. But it is clea that although this two-fold inclination has always been part of human make-up, what each of us considers a 'fellow' varies depending on whether we belong to traditional societies - in which class 
or family ties are still strong - or to modern societies - which are more autonomous - in which affinities are not, supposedly, pre-defined. It is in this latter case that fashion, with its clear fixation on appearances, may take on a particular relevance as a principle for social assimilation and distinction. This is why, without rejecting its existence in the past, we can nevertheless underline a particular affinity between the development of fashion and the modernization process, which began in western society and is spreading all over the world.

This particular affinity between fashion and modernization can be shown in several ways, some of which follow.

\section{The prestige of novelty}

Firstly, we find that the social distinction associated with fashion is linked to the prestige that 'something new' has acquired in modern societies, in surprising contrast to the prestige of 'antique' things in traditional societies. On this basis, we could define fashion as a characteristically modern expression of the social, temporal, and aesthetic dimension of human life. Its modernity resides in the fact that, in contrast with emphasis on what is old and permanent found in classic and traditional contexts, fashion emphasizes what is new and ephemeral. Therefore, even when it returns to manners and styles from the past, it does so in conformity with its characteristic pattern of constant change and it does so in such a way as to avoid settling on any of them. As Kant notes, 'Novelty makes fashion alluring; and to be inventive in all sorts of external forms, even if they often degenerate into something fantastic and even detestable, belongs to the style of courtiers, especially the ladies, whom others follow avidly' (Kant [1798] 1978, 7: 245).

The fashion boom favoured by our modern social structure could thus be taken as a sign of weakening tradition, and of the weakening of social links forged by tradition; in the same way as, according to Gabriel de Tarde ${ }^{6}$, modernity has also favoured the substitution of tradition with reason, and of reason with opinion. In any event, we should keep this background idea in mind in order to understand the Romantic-style dialectical reaction with which the cultural area attempts to resist change by appealing to identity. If we do not comprehend this type of reaction, we will never understand the paradox: the irony contained in the postmodern attempt to integrate fashion and identity, change and stability.

\section{Redefinition of social affinities}

We find another means of understanding fashion in modernity by remembering that the transition from the old to the new regime, together with the arrival of an industrial society, goes hand in hand with a progressive decline in the traditional significance of attire, which, while not being identical to fashion, is, however, at its 'epicentre'. Thus, while in traditional societies clothing indicated class,
6. 'Mucho antes de tener una opinión general y sentida como tal, los individuos que componen una nación tienen conciencia de poseer una tradición común, y

conscientemente se someten a las

someten a las decisiones de una razón considerada estas tres ramas del espíritu público, la última en desarrollarse, pero también la más dispuesta a crecer a partir de un cierto momento, es la opinión; y ésta se opinión, y ésta se de las otras dos (Tas de las otras dos' (Tard 1986: 80) 
7. There is however, a major difference between Veblen and Simmel. Whereas for Veblen, fashion can be explained in terms of ostentation of status, and therefore, leave itself open to interpretations where prestions where prestige and money are fused together, Simme offers a more carefully worked out version of the phenomenon, in that he explains fashion in terms of purely formal sociability - as a pure principle of assimilation and distinction in itself indifferent to the content of the expression. occupation, belonging to a certain region, etc., in modern society - with the exception of those areas where a purely logical function is the rule - clothes alone no longer indicate anything (Finkelstein 1998: 18; Crane 2000: 3), except possibly social position and sexual difference.

However, we find what defines fashion as such within this progressive emptying of significance, which leaves the meaning of attire at the mercy of changing social conventions. Fashion is thus defined by its condition of pure form empty of content and, for this same reason, all its strength and prestige come from social conventions. Accordingly, at a time when industrialization and the progressive democratization of our societies have annulled class differences, fashion, informed entirely by convention, has taken on a double role of assimilation and difference. This guarantees minimal social consistency, because there can be no society unless the dynamics for social assimilation and difference that Simmel, like Veblen before him, considered in terms of class are preserved.?

Like many others before him, Simmel emphasizes the role played by mimicry in this process. Although the phenomenon of mimicry merits a separate study - attending to the triadic structure of desire (Girard 1978) - here it is enough to admit that, from the outset, we imitate that which, consciously or unconsciously, we would like to be. Granting that this tendency is to be found, partially at least, at the roots of human sociability, we may infer the importance of guiding these ambitions in order to avoid the contamination of the social process, because - in the line indicated by Rousseau - it would be difficult to avoid the emergence and development of fashion itself. Certainly, the phenomenon of mimicry, when referring to fashion, has been expressed in different ways. In other ages, when fashion was a question of class, the bourgeoisie imitated the aristocrats. In the twentieth century, however, the models no longer came from the aristocracy. From the 1950s onwards fashion has clearly changed from being imposed from top to bottom to spreading from the bottom up (Crane 2000: 14) (for example 'cool-hunters', who search for what is 'cool' in the most stylish areas of the main European capitals), and although the need to use celebrity figures as 'loudspeakers' for tendencies has emerged, the mimicry remains.

However, Simmel himself pointed out that the mimicry cannot be complete because both society and fashion demand differentiation. So, for example, although the bourgeoisie did imitate the aristocrats, they always tried to avoid its excesses; and the aristocracy always introduced a new fashion when the earlier one had filtered down to the lower classes. Thus, social difference was preserved. Even now, when a particular fashion has been more or less accepted in the main, the brains behind it - no longer the traditional aristocracy, but creative sectors of the public, urban tribes, etc. - attempt to differentiate themselves again by launching a new fashion. The term 'attempt' does not necessarily mean 'explicit intention', but what is essential in the process is that, by setting a trend, an individual, intentionally or not, tries to be different in the same way that someone else, by imitating them - again intentionally or not - tries to express their social affinities. Meanwhile it is the concept of 'lifestyle', rather than the idea of class, which shapes people's affinities and the dynamics of fashion itself. 
The transition from 'class' to 'lifestyle' (Crane 2000: 10), already identified by Daniel Bell in his book The Cultural Contradictions of Capitalism, is in itself indicative of a third approach, previously mentioned, which again reveals the modernity of fashion. That is, its harmony with the modern process of individualization and, finally, with the Romantic desire to express one's own identity in such a way as to not be absorbed into a genre. In fact, Simmel had already clearly pointed out how, in the anonymity and functionality of great modern cities, fashion had become a channel to express human subjectivity (Finkelstein 1998: 107-108), in paradoxical harmony with the Romantic longing for one's true self and Nietzsche's ethics of distinction.

\section{Qualitative individualism}

Undeniably, the individuals Simmel observes at the beginning of the twentieth century are not exactly Romantic types. Living, as they were, in a highly industrialized society they could hardly indulge in Romantic spontaneity. While they still valued their subjectivity, and tried therefore to contest the homogenizing trends of their times, they found it hard to recognize themselves in nature. Leaving the city was no longer an option for them. In fact, the Romantic ideal of Bildung, consisting in the reconciliation of nature and freedom in one's own subjectivity, seemed lost forever. In the conditions of a culture, increasingly technical and alienated from its human author, that Romantic longing could only feed a tragic feeling about human destiny.

Simmel was aware of this alienation when he referred to the 'tragedy of culture' - that is, the lack of correspondence and synchronization between objective and subjective culture. In so doing, he was picking up a characteristically Nietzschean theme and it was precisely Nietzsche who first formulated a critique of the Romantic ideal of Bildung, suggesting an alternative solution for preserving a sense of one's self despite the conditions of modern life. His proposal no longer required the development of Bildung, but rather the acquisition of style.

In Nietzsche's view, style - not to be confused with fashion - is a strategy the subject develops to retain control of a situation, avoiding the invasion of the outside world into the realm of one's subjectivity. From this it is clear that having style involves a strong will. It is therefore not a matter for everybody, but for human beings completely in charge of themselves.

According to Simmel, individuals living in early-twentieth-century cities ran the risk of becoming interchangeable pieces in a huge social machine and were thus bound to find Nietzsche's aristocratism attractive. In the development of 'style', they discovered a way to preserve an individual sense of their selves, and control their manifestation. At the beginning of the twentieth century, style seemed the last refuge for those who struggled to resist complete functional homogenization. ${ }^{8}$

Clearly, Nietzsche's resort to style, as one mark of the superior human being, may be considered unrealistic and one-sided. In Simmel's view, Nietzsche represents the exaltation of humanity before society; because identity is linked to society, the Nietzschean individual has to resist identification
8. It is important to not that the general

relevance of style as a

mark of one's own

personality is a feature

of modern culture. This

is not to say that

people in the

pre-modern era had no

style or no interest in

style. It is just to say

that in pre-mode

times having a

personal - as opposed

to a class - style was

not deemed so

important in terms of

one's social identity.

Social identity was

developed out of other

developed out of other

sources. Pre-moder

individuals did not

have to worry mu

about their own

personal style. In any

event, they did not

experience it as a

matter of self-definition

or self-discovery, as a

matter of achieving or

expressing one's own

identity. Their social

identity came as a

identity came as

through the quite fixed

position they had in

their society by birth.

Tradition provided the

background against

which an individual

would develop his/her

taste. By contrast,

modern individuals

came to think of

identity as a task to be

achieved through

personal effort.

summarized this effort 
in a word: Bildung. Yet, Bildung was an overly ambitious ideal, which became unrealizable as industrial society imposed uniforming trends upon all individuals. At this the preserve anly way to pre's self was style. with any social group, with any group of reference. He cannot accept any definitions besides the one he gives himself. Nevertheless, as it turns out, this stylized version of human subjectivity has great difficulty resisting the influence of the consumer society.

Indeed, in the light of subsequent history, we might be led to think that this (supposedly final) refuge could not resist the attack of objective culture. In many cases, it certainly seems as if the advance of capitalist society has fulfilled the dark prognosis of Max Weber, who, through his metaphor of the iron cage (Weber [1930] 1956: 181) sees us going 'from the spirit of capitalism to capitalism without spirit'. In this way, the transition from productive capitalism to consumer capitalism would have finally succeeded in invading the fortress of subjectivity with its productions to the point of actually shaping people's desires far beyond all natural expectations. Significant in this context is the fact that the pages devoted to 'style' in most newspapers and magazines deal with consumer goods - as if having style were mostly a matter of having certain items. Has style perhaps not surrendered to the dictates of the fashion industry? Has not the subject disappeared behind the objects it consumes? Has not the subject, perhaps, fashioned an identity for him/herself according to the patterns of consumer behaviour? Is not identity something provided by the market, something to be appropriated and discarded like any other property?

\section{Professionalization of fashion}

In this final reflection we note the fourth way in which the process of modernization has affected fashion - particularly the production of clothing - by placing it within the general process of the division of labour that, thanks to the breakdown of the guilds, and the introduction of capitalism, led to the diversification of garment production and the professionalization of its manufacture. Thus, when, in 1857, Charles-Frederick Worth opened his couture house in Paris, he introduced the figure of the professional couturier and was surrounded by that aura of genius normally reserved for artists, it became clear that fashion would no longer begin in aristocratic circles. The professionalization of fashion brought it into the modern era once and for all.

Although almost 100 years would have to go by before the arrival of prêt-à-porter, and the marketing opportunities offered by the mass media would force the final aristocratic fashion connotations to give way to more 'democratic' fashion (Sommier 2000: 20), the fundamental economic structure has been laid down since then.

\section{Fashion and identity}

The 1960s marked the beginning of the cultural and social changes that led to the contemporary contentious linking of fashion and identity (Crane 2000: 14). As we have already stated, the seeds for this cultural change had already been sown by Romanticism, to which we owe the emphasis on 
identity - perhaps as means of steadying the constant movement brought about by modern times and the emphasis on self-expression, in dialectical contrast with the prevailing conventions of culture.

The 1960s witnessed revolutionary cultural change. Before then, daughters had followed their mother's fashion example; however, in the 1960s it was the mothers who imitated their daughters. Teenagers and young people largely became the focus of fashion - as had already been happening in the US since the 1950s. Haute couture lost ground as the innovator of trends, and in the following decades it was marginal subcultures that, one after another, took over as inventors of styles that were soon found everywhere.

This all seems to indicate that the idea of one single, top-down, hegemonic fashion would disappear and leave instead an unbounded pluralism - just like contemporary art, according to Danto, - that would be impossible to reduce to one single narrative and thus would be in comprehensible harmony with the postmodern exaltation of difference.

But is this difference real? Particularly from the 1980s onwards, we frequently feel that we are watching a manifestation that merely presents '(virtual) variations on a single theme': a manifestation that, far from promoting exceptional uniqueness, encourages - like in the Matrix movie - the elimination of discrepancies to the system. On occasion, the postmodern spectacle is presented as a gallery of identities, which the consumer may freely choose from, as if our very identity were nothing more than appearance and we could make use of it as we please.

Indeed, what is being sold lately in the name of fashion is not simply 'style', but 'identity'. Evidently, the sales departments have seen the demand for identity in a fragmented world and, when introducing a new product - be it a vehicle, a perfume, a vacation or, obviously, clothes - they try to connect it with a more or less stereotyped lifestyle or personality, something, in any event, unitary and superficially attractive. There is no need to be a Freudian or a Marxist to point out that our society, more fetish-oriented than ever, projects its most varied human illusions onto consumer products. In this way, we now sell appearance as identity.

The process that has brought us to this point has been long, drawn-out and not lacking in irony. It has been going on since the first appearance of fashion as a strategy for social assimilation and difference, based on conventional aspects which must be taken seriously - fashion as represented by a Simmel - until its postmodern deconstruction.

Beyond the differences between the diverse postmodern approaches, what they all have in common is the acceptance of the conventional nature of fashion, which Simmel has already underlined. Thus, instead of believing, as Simmel did, that maintaining these conventions is important both for society and for the individual, the different postmodern groups have differing opinions, either in direct confrontation with fashion conventions or by adopting a forcedly ludic attitude towards them.

In general, de-constructionist thinking on fashion begins by accepting the current increasing emptiness of meaning which we associate with clothing and other social manners and then declares 
that consumer society has carried out this emptying successfully: that we are now 'free' of any other meaning previously associated with objects (and can now use any other arbitrary meaning(s)). According to Baudrillard, the complete emptiness of meaning, which can convert an object into a pure fashion object, occurs when said object has been reduced to mere consumer goods. Once reduced in this way, it is also reduced to the mere condition of a symbol without meaning whose only significant power, therefore, would lie in referring to the remaining symbols of the system.

Continuing with Barthes's analyses, which link connotations of symbols and ideology (Barthes 1967), cultural studies scholars generally interpret the conventional and characteristic aspects of fashion as integral parts of a cultural system for social domination; this system is deemed to be responsible for the perpetuation of class differences and/or gender discrimination. The most evident example of this reading of fashion can be found in the interpretation of nineteenth-century fashion where Flügel identifies the 'Great Male Renunciation' (Flügel, [1930] 1971) as the disappearance of colour and the greater functionality of men's attire. At the same time, women's fashion - rich in ornamentation and poor in mobility - reflected man's conception of himself as an 'active being', in contrast with woman as a 'passive being'. Thus, by accepting the fashion of the period as an expression of their feminine identity, women more or less consciously accepted the position they were destined for within socio-economic structures.

By 'unmasking' the power structures that operate behind such an apparently trivial institution as fashion, the culturalist approach tries to strip fashion conventions of the strength and prestige they had in the modern vision. Thus, it gives the typically postmodern approach a chance; instead of taking the conventional aspects of fashion very seriously, as did the modern approach, it adopts a purely playful attitude towards them, which consecrates the concept of fashion as a mask, and, finally, what Bakhtin would call a 'carnivalesque' conception of life (Bakhtin ([1965] 1968).

So, once the 'perverse' nature of such conventions has been revealed, that is to say, once they have been finally reduced to their purely conventional status, we would be free to play with them, in a never-ending combination. This is particularly reflected in the Lipovetsky approach; in contrast with Baudrillard - for whom fashion, although aesthetic in its effects, is of economic origin Lipovetsky explicitly emphasizes fashion's aesthetic origin. Moreover, Lipovetsky interprets the global fashion phenomenon in more positive terms than Baudrillard. For the latter, indeed, the fact that fashion has been held up as a self-referential system, which promotes a certain kind of aesthetic liberation, may also reflect the failure of the political system in promoting individual autonomy (Finkelstein 1998: 75-6). In contrast, Lipovetsky believes that fashion, while not free of ambiguity, is a sort of catalyst for the modern process of individualization and it deserves global approval.

In any case, there is no room for anything really new in this self-referential system, nor can we expect it to reflect anything other than itself. Taking an example from Baudrillard, it makes no sense to interpret the miniskirt as a symbol of women's liberation, nor of women's oppression. It can only 
be interpreted as the opposite of the maxi-skirt. Similarly, consideration of fashion as a self-referential system explains how Baudrillard interprets the aesthetic dimension of fashion in terms of "recurrent circulation of forms" (Baudrillard 1993: 95). And while Lipovetsky does insist more on the idea of 'aesthetic innovation' as the engine for fashion, he does not actually introduce real innovation since the only innovation results from the simple combination of pre-existing elements and is, as Derrida would say, 'bricolage' (Barnard 1996: 167). Precisely from this combination, from this bricolage, Derrida draws on the postmodern idea and its peculiar notion of beauty: 'beauty' only comes from combining looks. On this basis, all the hopes of the postmodern individual are pinned on enjoying the seductive images and dreams promised by fashion - immersing himself/herself in the spectacle of virtual realities with changing forms.

In the meantime, what happened to identity? In its attempt to free the individual from the 'corset' of convention, postmodern discourse does not manage to give a positive answer to this question, unless we take the proposal of 'constructing' one's identity by means of the materials offered by the consumer society - including waste materials - as such.

Clearly then, the postmodern discourse - in particular its strange rhetoric of liberation reduced to bricolage - feeds on the situation created by the transition from the primitive capitalist production paradigm to the consumer paradigm of contemporary capitalism. This transition is accompanied by a change in accent in the fashion initiative - from the producer to the consumer - that may largely explain the anarchistic proliferation of styles and trends that have appeared since the 1960s, and which make it almost impossible to speak of a clearly defined fashion. We thus see an apparent mushrooming of offers because the individual is assumed - at least in his use of free time - to have the last word on fashion (Crane 2000: 11). Following this postmodern analysis, then, the individualizing dynamics, which are characteristic of the modernization process, find their ultimate expression in the figure of the aesthetic consumer.

But does this analysis reflect the truth? Is it not perhaps over-simplified?

\section{Fashion as an everyday phenomenon}

Although macroscopic and conflicting interpretations, such as those of Baudrillard or Lipovetsky, can undoubtedly help us to comprehend the elements involved in the key role of fashion in our contemporary societies, this very macroscopic character is also somewhat excessive. It ignores the everyday phenomenon of fashion, the way in which it appears in the very dynamics of social life independently of whether it has been cheered on by mass industry or not, independently of whether its agents behave as aesthetic consumers or simply as individuals who want to satisfy a need. As Veblen pointed out, no social class, no matter how poor, ever gives up on conspicuous consumption completely (Veblen 1994: 85). 
The everyday phenomenon of fashion is very well illustrated by Laura Bovone when she states that 'most of us have relatively little to do with fashion designers' suggestions, high fashion images, or prêt-à-porter purchases, but for all of us clothing is a duty, for some of us a pleasure, and for many of us a problem. This duty/pleasure/problem may sometimes find a solution in a glossy magazine, but, more often, we make our decisions when we open our full-to-overflowing wardrobes. We live in any case in the world of consumption, but what has been considered for many years as fashion - fashion that every year brings new prescriptions, rules that are temporarily accepted by everybody - is actually affecting our behaviours less. On the flip side, the cultural fashions of the moment - and our personal stock of clothes - have achieved greater importance, imposing slacker standards than before, but leading us away in different directions' (Bovone 2007: 87).

Only by paying attention to these everyday, microscopic decisions can we understand the relationship of fashion with identity and understand how fashion, either because of what we choose or what we involuntarily ignore, is an expression of what we are and, as such, is worthy of attention, precisely in relation to our identity. There are a few more words I would like to add on this issue.

When faced with the modern fixation of the subject in social conventions, or the postmodern 'solution' (or dissolution) of the subject in the flux of fashion, I believe it is of interest to explore the possibilities of an intermediate idea, of Aristotelian origin, repeatedly emphasized by Fernando Inciarte, which I reproduce here in a more conventional manner. The concrete substance (in contrast with the essence) is mutable and surrounded by things (accidents) that change; indeed, it is the substance itself that changes (accidentally) and, for this very reason, we convey, or betray the substance in its accidents. One consequence of this is what Inciarte himself writes elsewhere, 'The circumstances of life are very important, but what is at risk are not the circumstances, but rather the person himself' (Inciarte 2001: 223).

For the topic we are dealing with, we could interpret the idea as follows: identity (the concrete substance, biographical identity) is not conventional nor is it a matter that depends on fashion. However, we decide our identity in the way we assume different social conventions, including fashions, which implies an exercise in discernment on the subject of what is permanent and what is not within the changing circumstances of life.

Therefore, by definition, fashion is neither frivolous nor serious. However, a person is frivolous when they play around at an inappropriate moment or do not take something that needs attention seriously. Fashion is not in itself frivolous; in fact, understanding the language of fashion allows us to express our being by means of the demands of social life. As a means of expressing our identity and position in the world, the importance of fashion is based on the importance of the persons themselves, whose identity is strengthened in as far as it is properly expressed (Sommier 2000: 17).

Undoubtedly, we can say that a purely subjective identity, which is not revealed or is shown erroneously on the exterior, does not truly exist because existence implies externality. But this 
externality is not 'pure appearance', nor is it the more or less erroneous expression of a supposed 'interiority', but is, rather, us, ourselves, as we appear before others and express ourselves to them, mainly by means of behaviour and speech.

Fashion presents images and it may even suggest the illusion of a coherent personality and, in this way, seduce someone with a fragmented life. It may, perhaps, be used as a superficial means of social integration, especially for those who lack a defined identity (this explains groups of teens all dressed in the same way), but fashion, in itself, cannot, strictly speaking, provide identity. Even the teen who dresses in a certain way in order to belong to the group knows that what is truly important, in terms of identity, are the links of friendship with his companions, and the links he has or does not have with his parents (Sommier 2000: 19).

Although some ages and situations in life are more open to the influence of the dialectic logic of fashion, usually this influence is mediated by our awareness of our identity and the position we occupy in our own world. However, this awareness is, in turn, forged and consolidated by the same rhythm as the links that are sometimes real, but never apparent and that connect us to others. Only when these links are strong, only when we grow up in conversation with others, and not merely observing them, can we learn to choose which elements of fashion are suitable to express our identity and which are not. We also learn to choose which may be considered purely conventional, and thus can be played with, and which, in certain circumstances, may even be considered offensive.

\section{References}

Aristotle (1991), Politics, Cambridge, Cambridge University Press.

Baier, A. (1991), A progress of sentiments: reflections on Hume's Treatise, Cambridge, Harvard University Press.

Bakhtin, M. ([1965] 1968), Rabelais and His World, trans. H. Iswolsky, Cambridge: The MIT Press.

Barnard, M. (1996), Fashion as communication, London, New York: Routledge.

Barthes, R. (1967), Systéme de la mode, Paris: Seuil.

Baudrillard, J. (1993), Baudrillard Live. Selected interviews, ed. by Mike Gane, London, New York, Routledge.

Beck, U. (2002), Individualization: institutionalized individualism and its social consequences, London, Thousand Oaks, California, Sage.

Bourdieu, P. (2002), Distinction: a social critique of the judgement of taste, Cambridge: Harvard University Press. 
On fashion and fashion discourses

Bovone, L. (2007), 'Fashion, identity, social actor', in A. M. González and L. Bovone (eds), Fashion and identity: an interdisciplinary approach, Barcelona: Social Trends Institute.

Braudel, F. (1979), Civilisation materiélle, économie et capitalisme, XV-XVIIIe siècle, Paris: Colin.

Crane, D. (2000), Fashion and its social agendas. Class, gender, and identity in clothing, Chicago and London: The University of Chicago Press.

Elias, N. (1997), Über den Prozess der Zivilisation: soziogenetische und psychogenetische Untersuchungen, Frankfurt am Main: Suhrkamp.

Finkelstein, J. (1998), Fashion. An Introduction, New York: New York University Press.

Flügel, J. C. (1930/1971), The Psychology of Clothes, London: The Hogarth Press and The Institute of Psychoanalysis.

Girard, R. (1978), Mensonge romantique et vérité romanesque, Paris: Bernard Grasset.

González, A. M. (2004), 'Cultura y felicidad en Kant', Teorema, XXIII: 1-3, pp. 215-232.

González, A. M. (2007), 'Fashion, image, identity', in A. M. González and L. Bovone, Fashion and identity: an interdisciplinary approach, Barcelona: STI.

Goodman, D. (2001), 'Difference: An Enlightenment Concept', in K. Baker, What's left of Enlightenment? Stanford, Stanford University Press.

Hume, D. ([1777] 1975), Enquiries concerning Human understanding and concerning the principles of morals, $3^{\text {rd }}$ edition, with text revised and notes by P. H. Nidditich, Oxford: Oxford University Press.

Hume, D. ([1882], 1964), "Of the Rise and Progress of the Arts and Sciences", in The Philosophical Works. Essays Moral, Political and Literary, vol. 1, eds Th. Hill Green and Th. Hodge Grose, vol. 3, Scientia Verlag Aalen. Essays XIV (174-197).

Inciarte, F. (2001), 'Entrevista después de una autoentrevista', in Breve teoría de la España moderna, Pamplona: Eunsa.

Kant, I. ([1784] 1983), Idee zu einer allgemeinen Geschichte in weltbürgelicher Absicht/Idea for a Universal History from a Cosmopolitan Point of View (trans. Ted Humphrey), Indianapolis, Cambridge: Hacket Publishing Company.

Kant, I. ([1793] 1998), Die Religion innerhalb der Grenzen der blossen Vernunft/Religion within the Boundaries of Mere Reason (trans. and eds Allen Wood and George di Giovanni, intro. Robert Merrihew Adams), Cambridge University Press.

Kant, I. ([1798] 1978), Anthropologie in pragmatischer Hinsicht/Anthropology from a Pragmatic Point of view (trans. Victor Lyle Dowdell, intro. Frederick P. Van de Pitte, ed. Hans R. Rudnick), Carbondale, Edwardsville: Southern Illinois University Press. 
Ana Marta González

Kant, I. ([1802] 1923), 'Physische Geographie', in Kant's Werke, Band IX, Berlin und Leipzig: Akk.

Kant, I. ([1911] 1998), Kritik der reinen Vernunft, in Critique of Pure Reason (trans. and eds Paul Guyer and Allen Wood), Cambridge, Cambridge University Press.

Lipovetsky, G. (1994), The Empire of fashion. Dressing Modern Democracy, Princeton, New Jersey, Oxford, Princeton University Press.

Mauss, M. (1968), Sociologie et Anthropologie, Paris, Presses Universitaires de France.

Plato (1997), Complete Works, ed., with introduction and notes by John Cooper, associate editor,

D. S. Hutchinson, Indianapolis, Cambridge, Hacket Publishing Company.

Sennet, R. (1997), Carne y piedra. El cuerpo en la civilización occidental, Madrid: Alianza.

Simmel, G. (1971), On Individuality and Social Forms: Selected Writings, Chicago, University of Chicago Press.

Simmel, G. (1991), Schopenhauer and Nietzsche, Urbana, University of Illinois Press.

Smith, A. (1982), The Theory of Moral Sentiments, in D. D. Raphael and A. L. Macfie (eds), Indianapolis: Liberty Fund.

Sommier, E. (2000), Mode, le monde en mouvement, Paris: Village Mondial.

Tarde, G. (1986), La opinión y la multitud, Madrid: Taurus.

Taylor, Ch. (1992), The ethics of authenticity, Harvard University Press.

Veblen, Th. (1994), The Theory of Leisure Class, London: Routledge.

Weber, M. ([1930] 1956, The Protestant Ethic and the Spirit of Capitalism, trans. T. Parsons, New York, London, Charles Scribner's sons, George Allen \& Unwin Ltd.

\section{Suggested citation}

González, A. M. (2010), 'On fashion and fashion discourses', Critical Studies in Fashion and Beauty 1: 1, pp. 65-85, doi: 10.1386/csfb.1.1.65_1

\section{Contributor details}

Ana Marta González is Professor of Moral Philosophy at the University of Navarra (Spain), where she got her Ph.D. in 1997 with a research on the relationship between morality, reason and nature in Thomas Aquinas. Between 2002 and 2003, she was a Fulbright Scholar at Harvard, where she worked with Christine M. Korsgaard on Kant's practical philosophy. She has led several research projects exploring the intersection between moral philosophy and social theory, including, 'Estrategias de 
distinción social: perspectiva sociohistórica e interpretación filosófica' (2004-2006); 'Razón práctica y ciencias sociales en la ilustración escocesa: antecedentes y repercusiones' (2006-2009); 'Filosofía moral y ciencias sociales' (2009-); and 'Cultura emocional e identidad' (2010-). Her latest publications include, Practical Rationality. Scope and Structures of Human Agency (with Alejandro Vigo, Olms, 2010); Ficción e identidad. Ensayos de cultura postmoderna (Rialp, 2009); Kant's contributions to social theory (Kant Studien 1, 2009); Razón práctica en la ilustración escocesa (with Raquel Lázaro, Anuario Filosófico, 2009); Contemporary perspectives on natural law (Ashgate, 2008); 'Bioethics between nature and culture' (in Autonomy and Human Rights in Health Care: An International Perspective, D. Weisstub and G. Díaz Pintos (eds) 2008); Gender identities in a globalized world (with Victor Seidler, Humanities Press, 2008); Fashion and identity. An interdisciplinary approach (with Laura Bovone, 2007); Distinción social y moda (with Alejandro García, Eunsa, 2007); and 'Global Business in a Plural Society' (The Journal of Business Ethics, volume 44, 2003). Since 2004 Professor González has been the Academic Leader of the Culture and Lifestyles branch of the Social Trends Institute.

Contact: Departamento de Filosofía, Universidad de Navarra, Pamplona 31080, Spain.

E-mail: agonzalez@unav.es 


\section{Call for Submissions}

Intellect is actively seeking new photography book proposals. As a leading academic publisher in the fields of creative practice and popular culture, Intellect already has a strong list of visual culture and contemporary art focussed publications. We are keen to develop this area of our portfolio, and welcome proposals from both new and experienced authors producing original, adventurous scholarly work.

Since 1986, Intellect has provided a vital space for widening critical debate in new and emerging subjects. We aim to offer a platform for creative artists to present and critically reflect on their work.

To send us your book proposals, please download a questionnaire from our website or contact books@intellectbooks.com for further information.

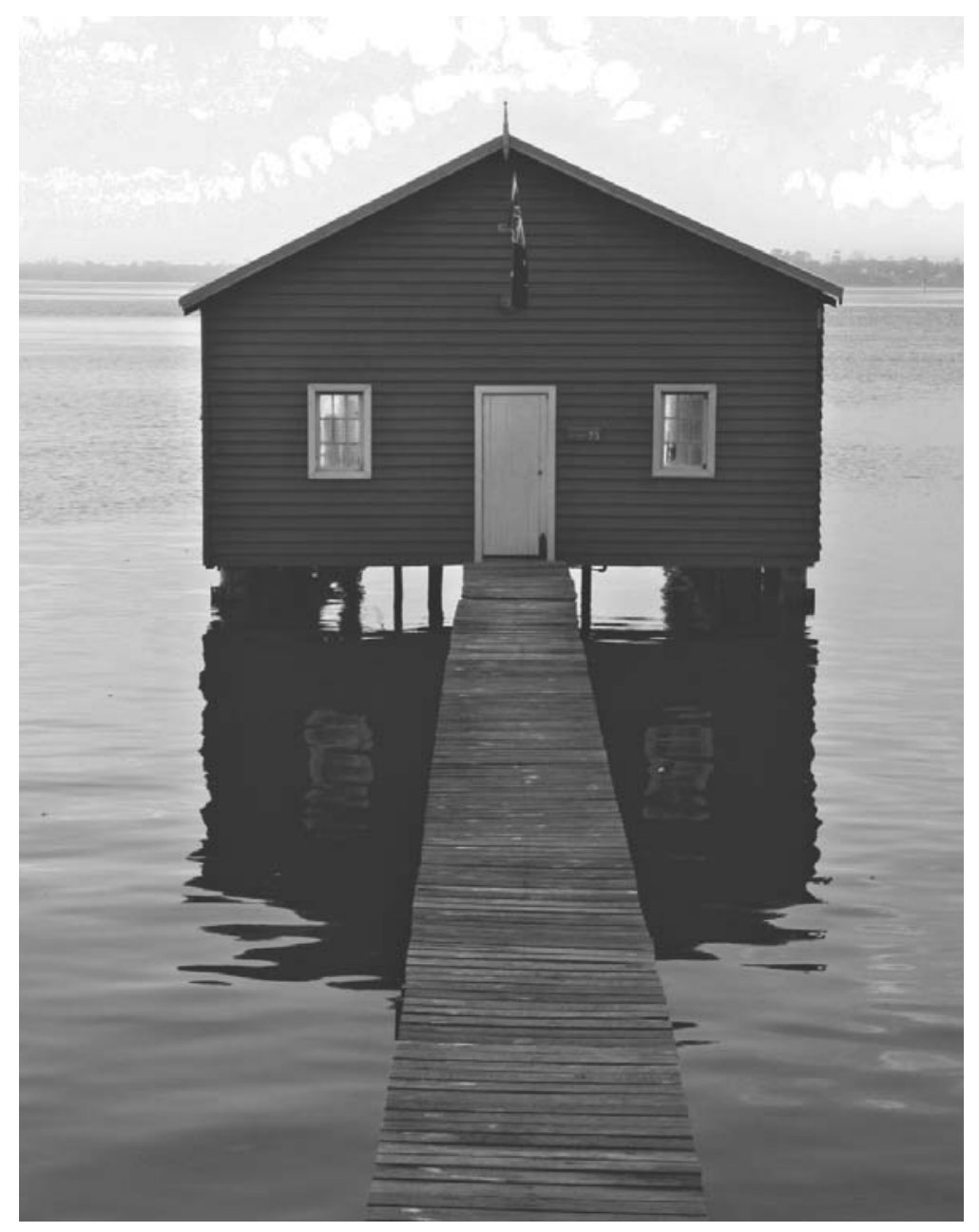

